\title{
STATE-CORPORATE CRIME AND MAJOR FINANCIAL INSTITUTIONS: INTERROGATING AN ABSENCE
}

\author{
David O. Friedrichs and Dawn L. Rothe
}

\begin{abstract}
The concept of state-corporate crime has been invoked and applied quite widely for more than 20 years now. We acknowledge the value of this concept but here address some of its conceptual limitations, especially in relation to crimes of large-scale investment and commercial banks, government-sponsored enterprises and international financial institutions. If the concept of state-corporate crime calls attention to the character and consequences of significant forms of crimes of the powerful, it tends to exclude attention to other forms of such crime. This article also addresses Steve Tombs' critique of state-corporate crime as it applies to what are here characterized as crimes of globalization. It considers the conundrum involved in a tension between achieving theoretical sophistication and in promoting effective responses to crimes of the powerful. It is a core premise of the analysis set forth here that in a rapidly changing, increasingly globalized twenty-first-century world, the forms of crime addressed here will necessarily attract more attention, especially relative to the traditional focus on conventional crime. A criminology that aspires to remain relevant in this environment must transform its understanding of crime.
\end{abstract}

Keywords: state-corporate crime; international financial institutions; crimes of globalization; systematic production of crime; criminological concepts of crime

\section{Introduction}

We should state at the outset that we have long held the conviction that the statecorporate crime concept is a highly useful contribution to the literature on crimes of the powerful, broadly conceived. We have long-standing ties with the two originators of this concept, Ronald Kramer and Raymond Michalowski, and have learned much from their work. Furthermore, we have addressed the state-corporate crime concept within our own work and have adopted it as a point of departure for some of this work (e.g. Friedrichs 2002, 2010; Friedrichs and Rothe 2013; Rothe 2009, 2010a, 2010b, 2010c; Rothe and Friedrichs 2014, 2015). We are also mindful of some of the criticisms of the state-corporate crime concept. One of us,

David O. Friedrichs, Department of Sociology/Criminal Justice, University of Scranton, USA, david. friedrichs@scranton.edu; Dawn L. Rothe, Department of Sociology/Criminal Justice, Old Dominion University, USA, drothe@odu.edu. 
in an earlier discussion of this concept, made note of the view that most, if not all, crimes carried out by either the state or by corporations involved some level of implicit or explicit cooperation between states and corporations (Friedrichs 2002). More recently, Steve Tombs (2012) advances the claim that states and corporations are increasingly in a symbiotic relationship leading to the systematic, routine production of crime and harm. In many circumstances, disentangling "state interests" from "corporate interests" is highly problematic due to the intersecting agendas of those at the top of both the state and the corporate hierarchies and the multiple "interlocks" reflected in movements in and out of high-level state and corporate positions. In the wake of the massive financial meltdown of the 2008-2009 period, many commentators have addressed how the government response was dramatically skewed to favour the interest of Wall Street financial "corporations", with many of the key top government officials involved (e.g. Secretary of Treasury Henry Paulson, a former Goldman Sachs CEO) either coming from these financial corporations or having multiple ties with them (Ferguson 2012; Madrick 2011; McLean and Nocera 2010). This circumstance is replicated throughout the world of the powerful and the privileged. Steve Tombs (2012) suggests that the bailouts in the midst of the financial crisis can be understood in terms of a symbiotic statecorporate crime relationship. Lines of demarcation between state and corporate entities, and between the public and the private realm, are blurred and opaque. While the concept of "state-corporate crime" can enrich our understanding of crimes of the powerful, it can also obscure some key dimensions of crimes in this realm. In the next section, this issue is addressed.

\section{The Paradox of Concepts: Clarifying and Excluding}

Many professional students of crime and criminal justice pride themselves with their disdain for the "interminable" definitional and conceptual discourses within the discipline, which are regarded as tedious and unproductive. Steve Tombs (2012: 170), in the opening paragraph of his critique of the state-corporate crime concept, refers to "tiresome" definitional debates. The guiding premise is that one should just "get on" with the work of documenting and explaining significant patterns of crime and its control without getting "bogged down" in "academic" debates about definitions and concepts. We acknowledge that definitional and conceptual discussions and debates can become excessively self-referential and unproductive and can inhibit the initiation and pursuit of substantive explorations of crime and its control. But we would also argue that the dismissal or marginalization of definitional and conceptual issues is one significant contributing factor to the field of criminology's historical pattern of focusing principally on the crimes of the poor and the powerless, rather than those of the rich and the 
powerful. White-collar crimes - and especially the crimes of states - were wholly ignored by most criminologists at least in part because immensely harmful and consequential activities in this realm were not captured by the "taken-for-granted" conventional definitions of crime. These broader definitional issues within the field of criminology are more fully addressed in a paper presented by one of the authors in an American Society of Criminology Meeting presidential panel on the definition of crime (see Friedrichs 2013b). Accordingly, they will not be further addressed here.

It has long been recognized that concepts such as "state-corporate crime" are both necessary and constructive dimensions of the project of making sense of an endlessly complex world, but they can also contribute to obscuring some dimensions of this world. Francis Bacon ([1620] 1963), writing hundreds of years ago, cautioned us not to forget that concepts are human creations and accordingly are not necessarily a wholly accurate reflection of the world. If the concept of "statecorporate crime" contributes to a fuller awareness of the immense significance of harmful (and criminal) cooperative endeavours involving states and corporations, it tends to exclude attention to a host of other powerful actors and a complex of other cooperative ventures with demonstrably harmful consequences in our world today.

The invocation of the terms "state" and "corporate" on both sides of the statecorporate crime equation always requires some qualification. In the broadest conception of "state", the term encompasses all citizens, from the humblest to the most powerful. In the broadest conception of the term "corporate" (or corporation), this term also encompasses everyone from the lowliest employee to the CEO. But state-corporate crimes are conceived of, are implemented by and, most especially, are very disproportionately beneficial to the state and corporate leadership class, and on the other side of this are disproportionately harmful to many other "stakeholders" falling under the "state" or "corporate" umbrella. It should also be useful to differentiate between state-corporate crimes carried out openly with a manifest rationale claiming broad benefits for both the state and the corporation - while concealing specifically illegal or unethical dimensions of the enterprise - and those state-corporate crimes directly benefitting the state and corporate leadership (or specific office-holding or executive leaders), with this type of corrupt enterprise consciously concealed on all levels. One of us has suggested, in an earlier analysis (Friedrichs 2002), that it might be useful as well to differentiate between those enterprises initiated by the public sector actors and those initiated by the private sector actors (i.e. state-corporate crime and corporate-state crime).

Altogether, the state-corporate crime concept has surely made a useful contribution to understanding crimes of the powerful by highlighting the especially 
potent (and sometimes deadly) effects of states and corporations engaging in mutually beneficial, cooperative initiatives that advance their common interests at huge cost to other stakeholders. The first anthology specifically dedicated to state-corporate crime (Michalowski and Kramer 2006) includes a series of articles documenting the daunting costs of state-corporate crime in a wide range of settings and contexts. In this article, however, we propose to focus on powerful entities in the world today that tend to either be marginalized within the existing state-corporate crime literature or have been wholly absent from it. These entities include large-scale investment and commercial banks, governmentsponsored enterprises (GSEs) and international financial institutions (IFIs). This listing is hardly exhaustive, as there are many other powerful financial actors in our world today, including the "shadow banking" system, hedge funds and credit rating agencies.

First, one has large-scale global private sector investment and commercial banks - exemplified by JPMorgan Chase \& Co., Goldman Sachs Group, Inc. and Citigroup Inc. - that are vastly powerful players in the world today. The GSEs - exemplified in the US by The Federal National Mortgage Association (Fannie Mae) and The Federal Home Loan Mortgage Corporation (Freddie Mac) - are a second major type of player in the world of high finance. And third, the term IFI here refers to the World Bank and the International Monetary Fund (IMF), which have long been major forces within the global political economy. The World Trade Organization (WTO) is often invoked in conjunction with these two entities, but as it is primarily a global regulatory entity, it functions somewhat differently from the World Bank and the IMF and accordingly requires a separate discussion. All of the aforementioned financial entities are not states - or, in a strict sense, state-run organizations - but they are also not corporations within the most commonly invoked meaning of this familiar term.

We next turn to a fuller consideration, in this context, of the two key conceptual components of the term state-corporate crime: "state" and "corporation".

\section{"State": A Problematic Term}

The growing inter-relationships between the state, international organizations, transnational corporations, the mass media and globalization generate a situation where the interplay and reinforcement of these processes in multiple institutions create profound implications for defining states. Moreover, as the state has been reified to the point of it being a seemingly natural institution, social scientists in general, and criminologists more specifically, often analyse the state without ever providing a clear definition of the concept. Within criminology, the term "state 
crime" has now been widely accepted. But what do we mean by the term state? Are we really talking about a "state" or a "government"? Is there a difference or do we mean the same thing? In the broadest sense, of course, a state refers to a defined territory that encompasses a population and a wide range of political actors and entities, from the city employee to the prisons to the president. In a stricter sense, a "state" is recognized as a sovereign-defined territory with a population that is under the control of a governmental apparatus that has the capacity to engage in formal relations with other states. The term "government" is more restrictive and refers to a specific political apparatus within a territory. Additionally, a state and a government must be seen as legitimate by the international political community and the citizens within, though these are not exclusive. A state can be viewed as legitimate but not the governmental regime (e.g. the Mohamed Morsi regime in Egypt), or a governmental regime can be viewed as legitimate but not the state (e.g. the Hamas regime in Gaza, Palestine).

We should note that our goal here is not to partake in the centuries-old debate of what constitutes a "state" or its role. Rather, given the restrictions of space, we draw on the body of state crime literature that recognizes that the use of the term "state" is problematic. In this context, the term state is represented by the actor or actors within the political apparatus that are entrusted with the power and legitimacy of a specifically defined territory and population to govern and that are acting in the name of or on behalf of the state (Rothe 2009). The approach to state crime taken here is in line with that taken by Michalowski (2010) and one of the authors (Rothe 2009) (see also Barak 1991; Chambliss 1989; Cohen 2001; Friedrichs 1998; Green and Ward 2004; Kramer 1994; Ross 2000; Rothe et al. 2009). Many scholars of state crime use the term "state" interchangeably with specific administrations and agencies (i.e. actors within them) that compose the political. In a general sense, state crime scholars accept the view that "state crime" is an action that violates domestic, international public law or causes serious social and personal harm through acts of omission or commission.

There are also scholars who believe all state crime can be classified as statecorporate crime (Kramer 1990; Kramer and Michalowski 1991; Kramer et al. 2002). Others have argued that there are distinctions between the two and not all state crimes are state-corporate insofar as state crimes can be motivated by religious, ethnic, personal ideologies or simply by political power (Mullins and Rothe 2008; Rothe 2009). Nonetheless, just as with much of the literature on statecorporate crime, most scholars of state crime do not focus on the interconnection between state crime and IFIs. We suggest that the relative neglect of major financial institutions in analyses of state-corporate crime is at least in part a function of the fact that they do not fit into the established conceptions of such crime. 


\section{"Corporate": A Problematic Term}

We live in a world where the corporate form is a hugely dominant element. Within criminology, the term "corporate crime" has now been widely accepted. But what do we mean by the terms corporate and corporation? In the broadest sense, of course, a "corporation" is any incorporated entity or any entity that has been awarded a corporate charter by some "state", broadly defined. In this broad application of the term corporation, it could include a very small business or partnership - strictly speaking, it could have a single shareholder - as well as a huge multi-billion-dollar multinational conglomerate. The key element in the legal definition of a corporation is that it is created by law, is separate from the individual or individuals who compose it and has the capacity for continued existence independent of the lifespan of the original individual or individuals who sought incorporation (Gifis 1975). In effect, a corporation is an "artificial person". The extent to which this "artificial person" should enjoy rights and privileges identical to - or directly analogous to - those extended to natural persons is, of course, a subject of huge, ongoing commentary and debate (e.g. see Clements 2012; Laufer 2006). Corporations may be characterized as not-for-profit, although the term is most readily associated with the profit-making form of a corporation. While the term corporation is most commonly associated with the private sector exclusively, there are public corporations - including townships and school districts - as well as entities such as the US Postal Service. The standard law dictionary recognizes other terms associated with "corporation", including "de facto" corporations and "quasi" corporations that operate like a corporation or fulfil certain corporate functions despite not having the actual authority of law as corporations. But the terms corporate and corporation, as invoked in the criminological literature, almost exclusively refer to large industrial corporations or corporations that produce or distribute material products and provide basic services, including automobiles, pharmaceutical products, oil and gas, food, air transportation and the like. This was true of E. H. Sutherland's (1949) pioneering White-Collar Crime and Marshall B. Clinard and Peter C. Yeager's (1980) contemporary classic, Corporate Crime, and it has remained true for most of the criminological work that has been published in the wake of these seminal contributions. There are some noteworthy exceptions to this proposition: that is, books by criminologists that have addressed the crimes within the Savings \& Loan thrifts in the 1980s (see Black 2005; Calavita, Pontell and Tillman 1997). But the Savings \& Loan thrifts were financial institutions which by definition - or by law - operated almost exclusively within a domestic framework. More recently, some criminologists have examined the criminal complicity of major investment banks in the financial crisis of 2008-2009 (Barak 2012; Hagan 2010; Will, Handelman and Brotherton 2013). Steve Tombs (2012) 
also addresses the financial crisis in relation to state-corporate symbiosis. But large banking institutions that increasingly operate on a transnational and global scale and engage in policies and practices with huge real-world consequences for billions of citizens worldwide have been the focus to date of relatively little criminological attention, including within the literature invoking the "state-corporate crime" concept. Furthermore, these institutions are profoundly interconnected to and operate systematically in relation to state institutions. We suggest that their relative neglect as a focus of criminological attention to date is at least in part a function of the fact that they do not fit so readily into the established categories or commonplace conceptions of either corporate crime or state-corporate crime.

\section{State-Corporate Crime and Large-Scale Investment and Commercial Banks}

We have suggested that the finance sector has been relatively neglected in both the white-collar crime literature and within the state-corporate crime literature. But what happens in this sector of the economy is immensely consequential. Furthermore, in the recent era, the financial sector in the US has expanded greatly relative to the political economy as a whole, as a function of various policies adopted in the 1970s and 1980s that turned out to hugely favour this sector (Antonio 2012; Davis 2009; Krippner 2011). As one illustration of this, "Between 1980 and 2007 , the finance sector share of profits tripled from a stable postwar average of $15 \%$ to a peak in 2002 of $45 \%$ of all profits in the US economy" (Lin and Tomaskovic-Devey 2013: 1284-1285). This "financialization" of the US economy has referred to both the rising dominance of the finance sector (including banks) and the increasing participation of non-finance firms in financial services and investment markets. The US economy has become less manufacture driven and more finance driven, with less "real economy" growth and more financial sector growth. As Robert Antonio (2012: 581) persuasively argues, the finance-driven economy is now operating like a giant Ponzi scheme:

[1]mposing exorbitant transaction costs, making the middle class dependent on the increasingly finance-driven stock market, appropriating resources from middling and poorly paid workers, failing to grow the real economy, and animating the transition of the US into a finance-based plutocracy ...

Many of the current problems in the US economy - including relatively high unemployment and a poor job market for prospective job-seekers of all ages, stagnant or declining incomes for middle- and lower-class workers, high rates of personal and business bankruptcy and foreclosures and losses of homes - can be attributed significantly to this transformation. A recent study has specifically 
demonstrated how the "financialization" of the US economy has contributed in a fundamental way to the rising income inequality in the US (Lin and Tomaskovic-Devey 2013). This "finance-led" capitalism has had severely harmful consequences for people in developing countries - for example, through gaming of the commodities market (Dullien et al. 2010). These harmful consequences of the transformation of the economy are "systemic" and pervasive, and insofar as state-adopted policies have been central to this transformation itself may be regarded as a large-scale form of state-corporate crime.

In the evolving US economy, then, the American heartland-based manufacturing corporations that have been the traditional focus of the corporate crime literature have become less important relative to the Wall Street-based financial institutions. One of us has argued, in multiple editions of Trusted Criminals, that the forms of white-collar crime that occur in the financial sector do not fit well under the heading of either corporate crime or occupational crime, but rather merit recognition as a separate form of such crime, finance crime (Friedrichs 2010). Crime in this sector alone has the capacity to threaten the basic stability of the political economy as was demonstrated in the 2008-2009 financial crisis - and top executives in this sector derive especially large rewards from institutional wrongdoing. The major investment banks and commercial banks have in some cases, famously, become "too big to fail" (Sorkin 2010). The forms of interdependence on and "cooperative" engagement with high-level state officials and entities are especially pronounced in the banking sector and are arguably greater than those involving the manufacturing corporate sector (Admati and Hellwig 2013). Disentangling the public from the private in this realm is particularly challenging. The public-private sector relationships involved are pervasive, ongoing and systemic. The enormous political clout of the financial sector largely defangs any legislative and regulatory initiatives to limit hugely risky (but highly profitable) banking policies and practices; politicians and regulators are all-too-comfortable with this "cozy cronyism" (Carruthers 2012; Cochrane 2013). Efforts to learn from and respond effectively to the "lessons" of past financial crises and catastrophes are trumped by this political clout and banks putting their own interests first and foremost.

In sum, the specific incidents of alleged wrongdoing in the finance/banking sector that surface publicly could be characterized as visible manifestations of ongoing, systematic forms of harm. In relation to the financial crisis of 2008-2009, a shelf-load of books has now been published exploring and documenting many different dimensions of the interconnections between Wall Street and Washington and the harmful consequences of these deeply entrenched interconnections (e.g. Ferguson 2012; Madrick 2011; McLean and Nocera 2010). Robert Rubin is just one among the countless such examples of state-financial institutions interconnections. He was a CEO of Goldman Sachs who subsequently served as Secretary 
of the Treasury in the William J. Clinton administration and then assumed a lucrative position with Citigroup. Rubin exemplified the dual role of Wall Street and government insider. Citigroup was a bank that made especially catastrophic decisions in the lead-up to the financial crisis, but Rubin disavowed any responsibility for these bad decisions. It is difficult in cases such as Rubin's and the many others with essentially parallel career tracks to clearly differentiate between public sector and private sector roles and initiatives as they become fundamentally intertwined. These ties exist on both the personal and the institutional levels. They are deeply entrenched, pervasive and ongoing.

The crimes of the major banks - and the financial sector more broadly - have been extensively documented (for an overview, see Friedrichs 2010). As was noted earlier, at least several criminologists have addressed the specific crimes which contributed to the financial crisis of 2008-2009 (e.g. Barak 2012; Friedrichs 2013a; Hagan 2010). The specific crimes involved in the financial meltdown include, but are not limited to, massive levels of fraud and fraudulent misrepresentations, various forms of market manipulation, blatantly dishonest accounting gimmicks and insider trading. Due to space considerations, the crimes of Wall Street are not further examined here. But one can assert that in many instances they exemplify the notion of state-corporate crime due to the public-private sector interlocks and cooperative initiatives involved.

The current status of the financing of political campaigns for office in the federal government brings into especially sharp relief the public/private sector ties and their hugely corrupting consequences. Harvard Law Professor Lawrence Lessig (2011) potently makes the case that the dependence of Washington on Wall Street (and other big money sources) for campaign funding and the huge Wall Street (and corporate) political lobbying apparatus has so fundamentally distorted political policy making that the US is no longer a "republic" in the sense intended by the Founding Fathers. For Lessig, unless Americans can find a way to get "big money" out of the political system - and he sets forth specific proposals for doing so - no substantial progress can be expected on other fundamental political policy issues. Although there are cases where congressmen (e.g. Randy Cunningham of California, William Jefferson of Louisiana) took bribes on a "quid pro quo" basis, and were caught, convicted and sent to prison, these conventional cases of criminal corruption are deemed to be reasonably uncommon within the contemporary American political system. The corrupting effect of big money in politics is systemic and far more corrosive overall:

The great threat to our republic today comes not from the hidden bribery of the Gilded Age, when cash was secreted among members of Congress to buy privilege and secure wealth. The great threat today is instead in plain sight. It is the economy of Influence 
now transparent to all, which has normalized a process that draws our democracy away from the will of the people. (Lessig 2011: 7)

Altogether, the real harm arising out of "state-corporate crime" in this realm is surely a function of the ongoing systemic relationships - as Tombs' critique suggests - rather than any specific cases where criminal wrongdoing might be demonstrated.

\section{State-Corporate Crime and GSEs}

There are other powerful actors in the financial sector that have also, to date, been left out of the criminological literature on corporate crime, on state crime and on state-corporate crime: to wit, GSEs. In the US, the huge mortgage investing entities Fannie Mae and Freddie Mac are neither state entities in a conventional sense nor corporate entities in a conventional sense. Fannie Mae was created in 1938 with the idea that it would impact favourably on the housing slump of the Great Depression by buying up mortgage loans from banks, thereby both reducing the risk of making such loans for the banks and freeing up further capital to allow these banks to make more mortgage available (Islam et al. 2013; Tully 2013). With the movement to privatize Fannie Mae during the late 1960s, Freddie Mac was created as a rival company and as a concession to critics concerned about Fannie Mae having monopolistic advantages as a private company. Altogether, over a period of many decades, Fannie Mae and Freddie Mac were widely regarded as having successfully fulfilled the objective of promoting the broader realization of the "American dream" for millions of middle-class families by making mortgage loans more widely available by buying up the mortgages originated by other parties. But through the "affordable-housing policies" adopted by the US Congress in the 1990s, the GSEs lowered their credit standards in relation to mortgages they bought up and accordingly acquired a huge volume of subprime mortgages that in large numbers went into default (Islam et al. 2013; Tully 2013). As a consequence, the GSEs contributed to the basic circumstances leading to the financial meltdown in 2008. These GSEs should be of special interest to students of state-corporate crime because they exemplify the hugely harmful consequences of cooperative initiatives between public and private sector entities with mutual incentives to engage in initiatives very disproportionately benefitting powerful insiders on both sides as opposed to other stakeholders and the broader public. On the political side, the top leadership of both the Republican and the Democratic parties found it appealing to promote policies that would make home ownership possible for segments of the electorate that had historically not been able to afford - or qualify for - mortgage loans to purchase homes. 
Accordingly, much political pressure surfaced promoting subprime mortgages. On the other side, the GSEs recognized that they could enhance their profits, at least in the short term, by purchasing subprime mortgage loans to the tune of billions of dollars. Of the many accounts of the financial meltdown, one in particular, Gretchen Morgenson and Joshua Rosner's (2011), claims for the GSEs and their top executives a central role in the financial meltdown. The various high-level political "friends" and "enablers" of the GSEs among the subprime loan originator companies (especially Countrywide Financial Corporation) also played a key role, as did "feckless" government regulators. The element of government "sponsorship" and the presumed or implicit - if not explicit - government "guarantee" of the financial commitments of the GSEs can be considered inherently criminogenic insofar as this sponsorship and guarantee promoted a relative indifference to excessive risk in the subprime mortgages purchased by the billions. The top personnel of the GSEs were very handsomely rewarded on the basis of the short-term huge numbers being reported by the GSEs, rather than long-term performance of the investments they were making. As it happens, both Fannie Mae and Freddie Mac had weathered crises involving allegations of fundamental misrepresentations in their financial statements through the use of suspect or outright fraudulent accounting.

Not all commentators have agreed with the special emphasis accorded the GSEs by Morgenson and Rosner (2011) as prime villains in the financial meltdown, but by any measure some significant level of culpability was surely present. In the wake of the financial meltdown of 2008, a massive bailout of them was undertaken by the US Department of Treasury, and the GSEs were placed in a "conservatorship" by the government, overseen by the Federal Housing Finance Agency, with a plan adopted to phase them out (Islam et al. 2013; Tully 2013). But as of 2013, Fannie Mae and Freddie Mac were bigger than ever and were guaranteeing 80 per cent of new home loans in the US worth trillions of dollars. This had the effect of squeezing out private lenders and of posing ongoing huge risks to taxpayers should another housing collapse occur.

Altogether, it would be difficult to identify a realm of financial activity where harmful policies and practices were more fully a function of profoundly intertwined cooperative and mutually beneficial actions of public and private sector parties or where harmful outcomes could be more directly attributed to "systemic" forces within the contemporary capitalist political economy.

\section{State-Corporate Crime and IFls}

We characterize the crimes of IFIs such as the World Bank and the IMF as "crimes of globalization", specifically because the conditions of rapidly expanding 
globalization give rise to this type of crime. If domestic and international banking institutions have been relatively neglected in the criminological literature - at least as perpetrators of criminal wrongdoing as opposed to victims of crime - in the case of IFIs, the criminological neglect has been almost total. Accordingly, we focus here especially on these IFIs. We do not claim that there are no exceptions to this alleged neglect of IFIs in the state-corporate crime literature. Nancy A. Wonders and Mona J. Danner (2006: 102) note that “... the IMF and World Bank have played a critical role in solidifying the relationship between internal national interests in developing countries and global economic interests". They go on to contend that the Structural Adjustment Programs (SAPs) imposed on developing countries have impacted negatively on citizens of these countries, with women suffering a disproportionate share of the harm. These harms are identified in relation to factory labour, environmental degradation and militarization in the developing countries. David Kauzlarich and Rick A. Matthews (2006: 246-247) assert that

A related area of concern that should receive close scrutiny from state-corporate crime researchers is the role of supra-governmental organizations such as the International Monetary Fund (IMF), the World Trade Organization (WTO), and the World Bank in shaping both structural conditions and control regimes that may either be conducive to or restraints against state-corporate crime.

Although the articles published in the Michalowski and Kramer (2006) state-corporate crime anthology address a range of hugely harmful forms of such crime, none specifically make the IFIs a primary focus of their analysis. In some of our recent work, we have attempted to address this relative neglect. One of us (Friedrichs 2010) has addressed crimes of globalization not as a sub-type of state-corporate crime but as a separate and somewhat parallel hybrid form of white-collar crime. In the present context, however, we have the objective of exploring a little more fully the nature of the relationship of crimes of globalization to state-corporate crime, taking into account Steve Tombs' (2012) critique of the state-corporate crime concept.

Crimes of globalization have attributes that exemplify the state-corporate crime concept, because virtually by definition they involve public or private sector cooperative initiatives. They are also illustrative of Tombs' theme about systemic relationships, because the harm of these crimes in developing countries in particular is a function principally of ongoing relationships and entanglements more than specific projects. The IFIs are neither state entities in the traditional sense nor are they corporate or private sector entities by any conventional definition of these terms. However, the relationships between these IFIs and crimes of states and state-corporate crimes are vast. In their introduction of the crimes of globalization concept, Friedrichs and Friedrichs (2002) discussed the 
impact of the World Bank's project, Pak Mun Damn, on the indigenous population and the local ecosystem. Specifically, the project involved cooperative endeavours between IFIs, transnational corporations and the state. Others have followed with research on the links between the state crime committed by Senegal and the role of the IFIs in the sinking of the Le Joola (Rothe, Mullins and Muzzatti 2006) and the role of IFIs in facilitating the genocide in Rwanda (Rothe, Mullins and Sandstrom 2009). One of the authors has also focused on how these IFIs have facilitated state corruption (Rothe 2010a, 2010b, 2010c). Research has also linked these institutions with the crimes of Indonesia in its brutal campaign against civilians in Timor-Leste (Stanley 2009).

Elsewhere, the authors have brought attention to how the crimes of IFIs have a generic relationship to state-corporate crimes, yet do not fit within the confines of the generally accepted concept of state-corporate crime (Rothe and Friedrichs 2015). We have also suggested that crimes of globalization are not best classified as transnational or international crimes. These terms are sometimes invoked in ambiguous or confusing ways. Transnational crimes, which often can be considered as state-corporate crimes, are forms of crime that are increasingly carried out across borders and via international or global networks. International crimes are best conceived of as violations of international law, which in their generic form (e.g. genocide, war crimes, crimes against humanity, massive violations of human rights) have a long history (Friedrichs and Rothe 2013). Here we have argued that while connections between the above categories (e.g. state-corporate crime, transnational crime, international crime) are not so easily separated in this emerging "globalized criminality", crimes of globalization have some unique dimensions independent of the forms of crime noted above. But they could not occur without the symbiotic relationship existing between corporations and states.

In a recent publication, we proposed an integrated theory that builds off of much of the state-corporate (and state) crime literature (Rothe and Friedrichs, 2014). However, we also noted that when it comes to efforts of citizens or states to hold IFIs accountable for their mass harms and crimes, there are some unique challenges. The IFIs operate with a singular absence of effective accountability and oversight. No international institutions specifically have jurisdiction over, take complaints on or adjudicate the broad range of harmful activities engaged in by the IFIs. This is in contrast to the "potential" venues of control or redress of statecorporate crimes, for example, the WTO or the European Court of Human Rights.

\section{Concluding Thoughts}

Steve Tombs (2012) is surely correct to recast state-corporate crime as more about ongoing symbiotic relationships and processes than about discrete actions 
and events. The state-corporate crime concept can be characterized as one step in the direction of a more sophisticated criminology, addressing as it does the crimes that emanate out of cooperative state and corporate activities. Steve Tombs' (2012) critique of the concept seeks to ratchet up the level of sophistication in our understanding of this form of crime by recasting state-corporate crime as reflective of symbiotic, ongoing relationships as opposed to the cooperative activities carried out by discrete and autonomous actors.

In relation to all of the major financial institutions we have addressed in the foregoing sections of this article, it is clear that the core source of harm resides in ongoing symbiotic relationships and processes, about a complex of interdependent ties between the IFIs, their sponsoring states (especially the US), multinational corporations and businesses in developed countries that both influence policy and benefit from their programmes and corrupt elite political and business leaders in developing states that sign off on IFI programmes in their countries. Accordingly, the specific actions of IFI development officers and others and specific IFI-sponsored projects and specific events that arise out of this (e.g. violent suppression of anti-dam protests) are manifestations of structural, systemic crimes, in any truly sophisticated accounting. But recasting the state-corporate crime of state entities and actors and major financial institutions in fundamentally structural terms also becomes problematic because it moves towards a notion of an inherently criminal system and away from more traditional, concrete and "manageable" conceptions of crime. After all, the criminological enterprise is historically rooted in relatively simplistic, uni-dimensional understandings of crime and criminality.

While we find Tombs' argument on the symbiotic nature of crime in this realm generally persuasive, we also raise in this context a conundrum that plagues the whole realm of crimes of the powerful and applies here as well: the further removed conceptions of crime are from concrete actors, the more challenging it becomes to focus public awareness of and attention to such crime and to promote mobilization and effective responses to such crime. Two recent crimes in the US - a mentally unbalanced young man murdering in cold blood young school children and some of their teachers and supervisors (Newtown) and two immigrant brothers drawn into Islamic fundamentalist beliefs detonating bombs killing and severely injuring marathon participants and spectators (Boston) - were accorded wall-to-wall media coverage, were the focus of intense and widely diffused public distress and anger and became part of larger public policy debates (e.g. on gun control and immigration laws). These were terrible crimes by any measure. But the crimes of the powerful encompassed by the state-corporate crime concept - and extensions or refinements of that concept addressed here - by at least some measures have far broader and more enduring harmful consequences and yet receive far less media coverage and public concern. The absence of concretely defined targets as opposed 
to something more diffuse surely contributed to the failure to sustain the Occupy Wall Street movement, at least in the short term. There is no easy solution to the conundrum identified here, but we need to continue addressing it.

We believe that a viable twenty-first-century criminology is increasingly attuned to complexity, not simplicity. Our overall projection is that state-corporate crime, crimes of globalization and other forms of crime involving powerful institutions will become an increasingly larger part of what is seen as "the crime problem", while conventional (or street) crime will be an ever more attenuated dimension of this problem, for all kinds of reasons. The systemic exploitation of developing countries by powerful institutions based in the developed countries is highly likely to be increasingly challenged - with multiple consequences - by citizens of the developed countries. The African continent has been the site of a long and terribleand ongoing - history of major crimes of the powerful, from state crimes of violence to systemic economic exploitation of indigenous populations (Mullins and Rothe 2008). Currently, trillions of dollars of oil and mineral resources remain trapped under the African soil (Keefe 2013). Meanwhile, wealthy developed countries are rapidly depleting their domestic supply of these resources. Historically, much of Africa's mineral and natural resource wealth has been exploited via state-corporate crime on a massive scale. Whether the remaining mineral and oil wealth of Africa will be extracted in a manner that, first and foremost, contributes to positive economic development in African countries, with citizens of these countries as primary beneficiaries, or through large-scale state-corporate crime where the extraction process principally enriches a small number of corrupt state leaders and greedy private sector investors and corporations, remains to be seen. But it is difficult to overstate what is at stake in how this plays out, going forward.

In sum, we hope we have made a contribution here towards extending the conception of state-corporate crime to incorporate entities typically excluded from consideration in this context: major investment and commercial banks, GSEs and IFIs. We have every reason to anticipate that state-corporate crimes encompassing such entities will be huge dimensions of the twenty-first-century criminological environment. The sophisticated understanding of such crime and the complex relationships involved needs to be a core project for twenty-firstcentury criminologists.

\section{References}

Admati, A. and Hellwig, M. (2013) The Bankers'New Clothes. Princeton: Princeton University Press. Antonio, R.J. (2012) “After Neoliberalism: Whither Capitalism?" in G. Ritzer, ed., Companion Sociology. Boston: Wiley-Blackwell.

Bacon, F. ([1620] 1963) "Novum Organum”, in F. Bacon, ed., The Complete Essays of Francis Bacon. New York: Washington University Press. 
Barak, G. (1991) Crimes by the Capitalist State: An Introduction to State Criminality. Albany: State University of New York Press.

— (2012) Theft of a Nation: Wall Street Looting and Federal Regulatory Colluding. Lanham: Rowman \& Littlefield.

Black, W.K. (2005) The Best Way to Rob a Bank Is to Own One. Austin: University of Texas Press.

Calavita, K., Pontell, H.N. and Tillman, R.H. (1997) Big Money Crime: Fraud and Politics in the Savings and Loan Crisis. Berkeley: University of California Press.

Carruthers, B.G. (2012) "What's Haute in the Sociology of Finance?" Contemporary Sociology 41(6): 739-747.

Chambliss, W. (1989) "State-Organized Crime", Criminology 27(2): 183-208.

Clements, J.D. (2012) Corporations Are Not People. San Francisco: Berrett-Koehler Publishers.

Clinard, M.B. and Yeager, P.C. (1980) Corporate Crime. New York: Free Press.

Cochrane, J.H. (2013) "Running on Empty", The Wall Street Journal, 2-3 March, pp. C5-C6.

Cohen, S. (2001) States of Denial: Knowing about Atrocities and Suffering. Cambridge: Polity Press.

Davis, G.F. (2009) Managed by the Markets: How Finance Re-Shaped America. Oxford: Oxford University Press.

Dullien, S., Kotte, D.J., Marquez, A. and Priewe, J. (2010) The Financial and Economic Crisis of 2008-2009 and Developing Countries. New York: United Nations.

Ferguson, C.H. (2012) Predator Nation: Corporate Criminals, Political Corruption, and the Hijacking of America. New York: Crown Business.

Friedrichs, D.O. (ed.) (1998) State Crime (vols I and II). Aldershot: Ashgate.

Friedrichs, D.O. (2002) "State-Corporate Crime in a Globalized World: Myth or Major Challenge?" in G.W. Potter, ed., Controversies in White-Collar Crime. Cincinnati: Anderson.

(2010) Trusted Criminals: White Collar Crime in Contemporary Society (4th ed.). Belmont: Wadsworth/Cengage Learning.

_ (2013a) "Wall Street: Crime Never Sleeps", in S. Will, S. Handelman and D. Brotherton, eds, How They Got Away with It: White Collar Criminals and the Financial Meltdown. New York: Columbia University Press.

_ (2013b) "Transcending the Conventional Definition of Crime: Toward a Twenty-First Century Criminology", A paper presented at the annual meeting of the American Society of Criminology, Atlanta, November.

Friedrichs, D.O. and Friedrichs, J. (2002) "The World Bank and Crimes of Globalization: A Case Study", Social Justice 29(1/2): 12-36.

Friedrichs, D.O., and Rothe, D.L. (2013) "Crimes of Globalization as a Criminological Project", in F. Pakes, ed., Globalization and the Challenge of Criminology. London: Routledge.

Gifis, S.H. (1975) Law Dictionary. Woodbury: Barron's Educational Series.

Green, P. and Ward, T. (2004) State Crime: Governments, Violence and Corruption. London: Pluto Press.

Hagan, J. (2010) Who Are the Criminals? The Politics of Crime Policy from the Age of Roosevelt to the Age of Reagan. Princeton: Princeton University Press.

Islam, M., Seitz, N., Millar, J., Fisher, J. and Gilsinan, J. (2013) "Fannie Mae and Freddie Mac: A Case Study in the Politics of Financial Reform", Journal of Financial Crime 20(2): 148-162.

Kauzlarich, D. and Matthews, R. (2006) "Taking Stock of Theory and Research", in R.J. Michalowski and R.C. Kramer, eds, State-Corporate Crime: Wrongdoing at the Intersection of Business \& Government. New Brunswick: Rutgers University Press, pp. 239-250.

Keefe, P.R. (2013) "Buried Secrets", The New Yorker, 8-15 July, pp. 50-63.

Kramer, R.C. (1990) "From White-Collar to State-Corporate Crime", Conference Paper, North Central Sociological Association, Louisville, 22 March.

_ (1994) "State Violence and Violent Crime", Peace Review 6(2): 171-175.

Kramer, R.C. and Michalowski, R.J. (1991) "State-Corporate Crime", Paper prepared for American Society of Criminology Meeting, Baltimore, 7-12 November 1990, revised: September 1991.

Kramer, R.C., Michalowski, R.J. and Kauzlarich, D. (2002) "The Origins and Development of the Concept and Theory of State-Corporate Crime", Crime \& Delinquency 48(2): 263-282. 
Krippner, G.R. (2011) Capitalizing on Crisis: The Political Origins of the Rise of Finance. Cambridge: Harvard University Press.

Laufer, W.S. (2006) Corporate Boards and Guilty Minds: The Failure of Corporate Criminal Liability. Chicago: University of Chicago Press.

Lessig, L. (2011) Republic, Lost: How Money Corrupts Congress - and a Plan to Stop It. New York: Twelve.

Lin, K.-H. and Tomaskovic-Devey, D. (2013) “Financialization and US Income Inequality, 1970-2008”, American Journal of Sociology 118(5): 1284-1329.

Madrick, J. (2011) Age of Greed: The Triumph of Finance and the Decline of America, 1970 to the Present. New York: Alfred A. Knopf.

McLean, B. and Nocera, J. (2010) All the Devils Are Here: The Hidden History of the Financial Crisis. New York: Portfolio.

Michalowski, R. (2010) "In Search of State and Crime in State Crime Studies", in W. Chambliss, R. Michalowski and R. Kramer, eds, State Crime in the Global Age. Cullompton: Willan Publishing.

Michalowski, R.J. and Kramer, R.C. (2006) State-Corporate Crime: Wrongdoing at the Intersection of Business \& Government. New Brunswick: Rutgers University Press.

Morgenson, G. and Rosner, J. (2011) Reckless Endangerment: How Outsized Ambition, Greed, and Corruption Led to Economic Armageddon. New York: Times Books.

Mullins, C.W., and Rothe, D.L. (2008) Blood, Power, and Bedlam: Violations of International Criminal Law in Post-Colonial Africa. New York: Peter Lang.

Ross, J.I. (ed.) (2000) Varieties of State Crime and Its Control. Monsey: Criminal Justice Press.

Rothe, D.L. (2009) State Criminality: The Crime of All Crimes. Lanham: Lexington Books.

— (2010a) "Dragon Rising: The International Financial Institutions and China's Aid Policy on Weakened States", in W. Chambliss, R. Michalowski and R. Kramer, eds, State Crime in the Global Age. Cullompton: Willan Publishing.

_ (2010b) "Facilitating Corruption and Human Rights Violations: The Role of International Financial Institutions", Crime, Law and Social Change 53(5): 457-476.

- (2010c) "International Financial Institutions, Corruption and Human Rights", in M. Boersma and H. Nelen, eds, Corruption and Human Rights. Antwerp: Intersentia.

Rothe, D.L. and Friedrichs, D.O. (2014) "Controlling Crimes of Globalization: A Challenge for International Criminal Justice", in W. de Lint, M. Marmo and N. Chazal, eds, Crime and Justice in International Society. London: Routledge, pp. 246-266.

(2015) Crimes of Globalization. London: Routledge.

Rothe, D.L., Mullins, C.W. and Muzzatti, S. (2006) "Crime on the High Seas: Crimes of Globalization and the Sinking of the Senegalese Ferry Le Joola", Critical Criminology: An International Journal 14(2): 159-180.

Rothe, D.L., Mullins, C.W. and Sandstrom, K. (2009) “The Rwandan Genocide: International Finance Policies and Human Rights", Social Justice 35(3): 66-86.

Rothe, D.L., Ross, J., Mullins, C., Friedrichs, D., Barak, G., Kramer, R., Kauzlarich, D. and Michalowski, R. (2009) "That Was Then, This Is Now, What about Tomorrow? Future Directions in State Crime Studies”, Critical Criminology: An International Journal 17(1): 3-13.

Sorkin, A.R. (2010) Too Big to Fail. New York: Penguin Group.

Stanley, E. (2009) Torture, Truth and Justice: The Case of Timor-Leste. New York: Routledge.

Sutherland, E.H. (1949) White-Collar Crime. New York: Holt, Rinehart and Winston.

Tombs, S. (2012) "State-Corporate Symbiosis in the Production of Crime and Harm", State Crime 1(2): 170-195.

Tully, S. (2013) "The Rebirth of Fannie \& Freddie", Fortune, 1 July, pp. 91-95.

Will, S., Handelman, S. and Brotherton, D. (eds) (2013) How They Got Away with It: White Collar Criminals and the Financial Meltdown. New York: Columbia University Press.

Wonders, N. and Danner, M. (2006) "Globalization, State-Corporate Crime, and Women", in R.J. Michalowski and R.C. Kramer, eds, State-Corporate Crime: Wrongdoing at the Intersection of Business \& Government. New Brunswick: Rutgers University Press, pp. 98-115. 